Scientific Journal Warsaw University of Life Sciences - SGGW

Problems of World Agriculture volume 17 (XXXII), number 4, 2017: 151-160

DOI: 10.22630/PRS.2017.17.4.91

Ewa Koreleska $^{1}$, Andrzej Ferenc

${ }^{1}$ UTP University of Science and Technology in Bydgoszcz

${ }^{2}$ Nicolaus Copernicus University in Torun

\title{
Functioning of "Organics Cluster" in the French National and Regional Market of Organic Food
}

\begin{abstract}
The main aim of this study is to identify a model organic food cluster situated on the territory of a selected European Union country and its operation effects. In the first part of the study a selected food market of France is characterized as a reference point of further analyses and studies. The data was obtained from French domestic reports which cover years 2007-2016. Dynamics of changes has been defined as well as the trends characteristic of the analyzed period. The method of least squares has been used. Moreover, a definition and the importance of clusters has been presented on the basis of the literature of that topic. The part of the study includes a description of functioning of a selected French organic food cluster is described and evaluated. The method of case study has been used. It has been found that in 2007-2016 the eco-sector in France has developed significantly. A distinctly rising linear trend in the number of organic farms, ecological companies, ecologically cultivated land, the size of the market and degree of French people's knowledge of organic food labels has been reported for the eco-branch in France. As many as 112 projects have been implemented in the analyzed cluster. Those projects involved innovative and export undertakings which allowed to achieve a competitive advantage on the domestic market and even abroad. Positive effects also include possibility of experience exchange and financial support particularly important for young entrepreneurs.
\end{abstract}

Key words: cluster, organic food, organic farming, organic market, integration, France

JEL Classification: Q13, Q17, M3

\section{Introduction}

In literature there are many definitions of clusters (Kacprzak, 2014). According to the most popular definition of Porter (2001) it is: "geographical concentration of interrelated companies, specialist suppliers, service providers, companies and organizations of related sectors (for example universities, normalization committees and trade associations) in particular areas, competing with each other though cooperating at the same time". According to the definition a cluster needs to fulfill the following three conditions: Concentration of organizations functioning within the same or related sectors in a specific area, interaction of these organizations and existence of vertical and horizontal bonds connecting the cooperating parties (Duczmala, Potwory, 2010). It is estimated that in Poland there are only few ecological agri-food clusters and sometimes they end up unsuccessfully. Low dynamics of integration activities applies to all Polish agriculture (Prus, 2006, 2008), both conventional and organic. Clustering takes only a little advantage of the potential of the Polish ecological agriculture (Kacprzak, 2014). Therefore, it is good

${ }^{1} \mathrm{PhD}$ Eng., Faculty of Management, UTP University of Science and Technology in Bydgoszcz, ul. Fordońska 430, 85-790 Bydgoszcz, e-mail: Ewa.Koreleska@utp.edu.pl; https://orcid.org/0000-0002-7277-7519

${ }^{2}$ MD, Nicolaus Copernicus University, Collegium Medicum in Bydgoszcz, Faculty of Health Sciences, Jan Biziel University Hospital No. 2, ul. Ujejskiego 75, 85-168 Bydgoszcz, e-mail: andrzej.ferenc@cm.umk.pl 
to look for positive examples in other countries. Such an example could be used as a point of reference for Polish organizations as part of e.g. the benchmark method, involving comparison of an organization with other companies successful in a given field, learning from them and taking advantage of their experiences to use them in practice (Loda, 2012). In Europe, most of the clusters are situated in the well developed countries of UE-15, among which France and Luxemburg have the best developed cluster oriented policy implemented at the domestic level (Pilarska, 2010). The number of clusters puts France in third place as compared to other European Union countries. Only Germany and Italy are higher in the ranking. The total number of 125 clusters are reported to be located in France (Pilarska, 2013).The main aim of this study is to identify a model organic food cluster functioning on the territory of a selected European Union country and its operation effects. The following part aims have been determined:

- presentation of the concept and importance of clusters,

- characteristics of the organic food market in a selected European Union country,

- identification of operation effects of a selected organic food cluster.

\section{Research methods}

\section{Overview on the French Organic Market}

In the first part of the study, the French market for organic food is characterized in order to provide a background for further research and analyses. The data come from French domestic reports from 2007-2016 (including reports provided by AgenceFrançaise pour le Développement et la Promotion de l'AgricultureBiologique). The dynamics of change and trends characteristic of this period have been defined on the basis of the obtained data. The method of the least squares was used in the study. Parameters of the trend function equation (linear, square) were determined by means of this method (using Excel 2007 Microsoft Office). As a study area, the Rodan-Alpian regional organic food market has been selected as case study (currently Overnia-Rodan-Alpian).

\section{Literature review}

In the second part of the study a general review on the definition and importance of clusters in the food sector is presented based on current literature.

\section{Case study}

The last part of the study focuses on the presentation and evaluation of the selected cluster. The method of case study analysis has been used. The selection case study area was done on multiple, step-wise approach. The first step involved choosing a country on the basis of size of the organic market. Initially, three countries from the top of the European ranking report 'The World of Organic Agriculture. Statistics and Emerging Trends 2017', were taken into consideration, that is, Germany, France and the UK (Willer, Lernound, 2017).

Next, in the second step the European Observatory of Clusters was used (www.clusterobservatory.eu). Initial selection of clusters was made according to the sectorbased criterion - 'organic food'. It was found that most clusters, that is three, are located on the territory of France. On the basis of Innovation Clusters in Europe Report, a cluster located on the territory of a region characterized by the highest level of innovativeness and with the biggest number of strong clusters, as compared to other regions of France, was chosen for analysis. It is Rodan-Alpian (currently Overnia-Rodan-Alpian) region 
(Innovation Clusters in Europe, 2013). It was also the cluster policy and the number of cluster structures that affected the choice of a cluster to be analyzed (Brodzicki, Szultka, 2002). Primary data on the selected cluster was obtained by using an online survey with the use of a measuring instrument - survey questionnaire addressed to the director of 'Organics Cluster', which was supplemented by secondary data from a website 'Organics Cluster'. The survey was carried out in 2017.

\section{Characteristics of the organic food market in France}

The organic food sector in France developed rapidly during the last few years. A constant growth in the number of organic farms, the area of ecological plant production and the number of entrepreneurs involved in the organic sector has been reported. At the end of 2016 the number of ecological food producers in France was 32326 and in relation to 2007 it increased by 2.7 times (fig. 1). Most organic farms were established in 2010 (4158) and recently in 2016 (3442). The highest dynamics of change in relation to the previous year was observed in 2010 (by 25\%). The share of the number of ecological farms in the total number of farms in France has also been constantly increasing and today it accounts for $7.27 \%$ (tab. 1) (Agence Bio, 2017A).

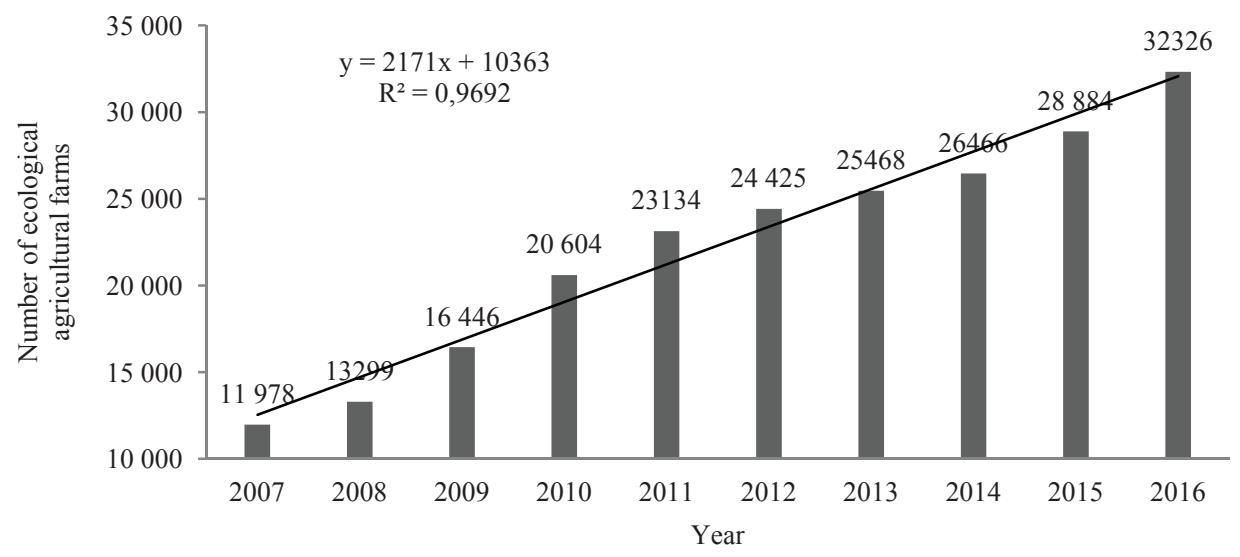

Fig. 1. Number of organic farms in France in 2007-2016

Source: own research according to Agence Bio/OC In: AgenceBio 2017.

The area of organic farmland has increased along with an increase in the number of organic food producers (fig. 1, fig. 2). In 2017 it is 1537000 ha and has grown as compared to 2007 by 953876 ha, that is 2.8 times. Between 2007-2016 the highest growth in relation to the previous year was observed for 2016 - by 214798 ha. The highest dynamics of change was observed in 2010 (by 25\%). The share of organic farmland related to the agricultural usable area in France is $5.7 \%$ (tab. 1) (Agence Bio, 2017A). 


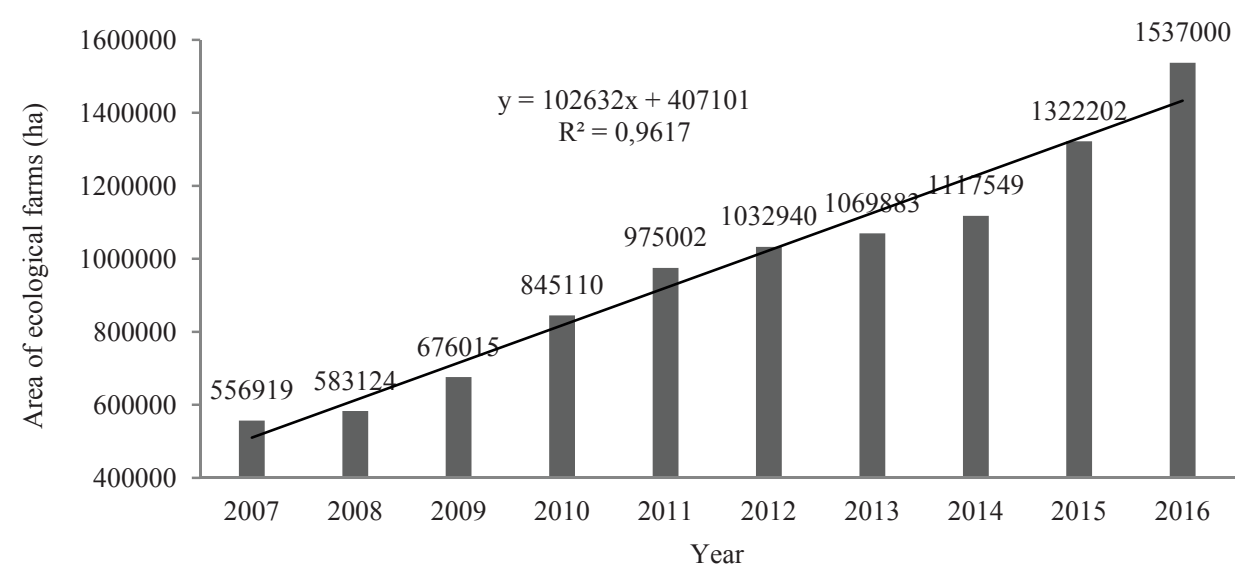

Fig. 2. The area of ecological farms in France, in 2007-2016

Source: own research according to Agence Bio/OC In: La bio change d'échelleenpreservantsesfondamentaux! Agence Bio 2017.

In 2016 the number of the processing companies in the organic sector (including manufacturing and trade, but excluding farms) was 14859 and increased in relation to 2007 by 2.3 times. Moreover, an analysis of data for 2007-2016 shows that the highest number of new business entities (1700) were registered in 2010. This year also features the highest dynamics of change as compared to the previous year, that is an increase by $19 \%$ (Agence Bio, 2017A).

In 2016, the largest group of all the registered businesses (14859) represented manufacturing companies (10 627, 71.52\%), half of which accounted for companies involved in bakery, confectionery products and other cereal products (fig. 3).

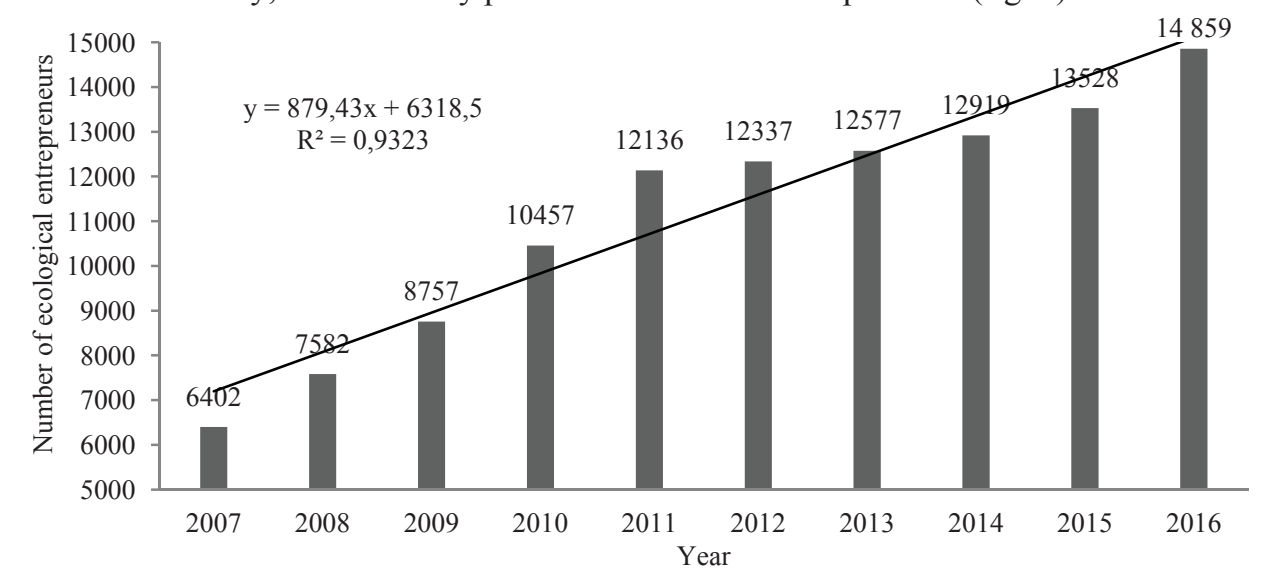

Fig. 3. Number of ecological entrepreneurs (manufacturing companies, trade companies, exporters and importers) in 2007-2016

Source: see fig. 2 . 
Table 1. Share of the number of farms and ecological croplands in France in 2007-2016

\begin{tabular}{c|cc}
\hline Year & $\begin{array}{c}\text { Share of organic farms related to the total } \\
\text { number of farms in France }\end{array}$ & $\begin{array}{c}\text { Share of organic farmland related to total } \\
\text { usable agricultural area }\end{array}$ \\
\hline 2007 & 2.11 & 2.03 \\
2008 & 2.41 & 2.14 \\
2009 & 3.07 & 2.48 \\
2010 & 3.96 & 3.12 \\
2011 & 4.58 & 3.60 \\
2012 & 4.98 & 3.82 \\
2013 & 5.34 & 3.96 \\
2014 & 5.79 & 4.14 \\
2015 & 6.50 & 4.91 \\
2016 & 7.27 & 5.70 \\
\hline
\end{tabular}

Source: see fig. 2.

In 2016 the general trade in organic food was 7 billion euro and was systematically increasing in the analyzed period (fig. 4) (Agence Bio/CSA, 2015). On the French market organic food is available in different sales channels. In 2015 the retail sale was prevailing and the sale of organic products in supermarkets (2 469 million euro), accounted for $42.87 \%$ of the total amount of organic food sold in France (in 2016, 3024 million euro). However, the trade in organic products in specialist organic stores in 2015 was 2019 million euro which put this kind of sale in second place $(35.06 \%)$. Direct sale was found to be the third significant point of sale (13.41\%). Sale of organic products in bakeries was not of high importance $(4.76 \%)$ and neither was the catering industry $(3.91 \%)$. A change in the hierarchy of distribution channels importance was observed in the period analyzed. In 2007, still most of the sales were carried out through specialist distribution channels. From the following year and up to today, supermarkets became the most important outlet. The shares of the remaining distribution channels did not change (Agence Bio, 2017A; 2017B).

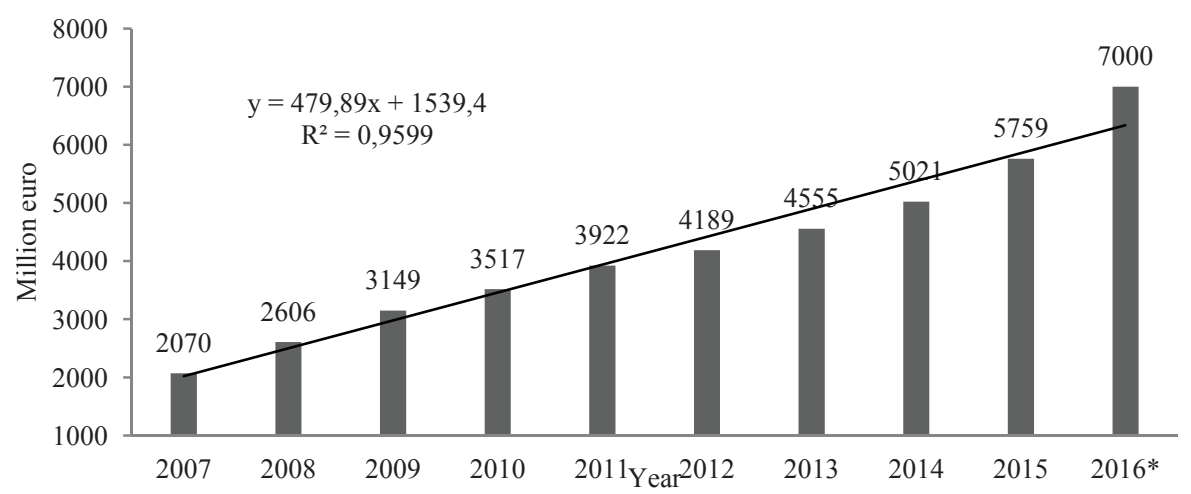

Fig. 4. The value of organic food sale in France in 2007-2016

Source: own research according to Baromètre de consommation et de perception des produitsbiologiquesen France 12 ème édition - 1ère chase, Agence Bio/CSA. 
According to the latest research almost 9 in 10 of French citizen (89\%) state that they have eaten organic products during the last 12 months. The share of regular consumers who consume organic food at least once a month is constantly increasing and has reached $69 \%$ (Agence Bio, 2017A).

The French who consume organic food, mostly buy organic fruits and vegetables $(78 \%)$. The next category of products which consumers choose are dairy products $(71 \%)$. In addition, organic eggs are in high demand (65\%), too. Slightly more than half of the French organic consumers choose cereal products $(51 \%)$, whereas almost half of the respondents $(49 \%)$ are interested in organic meat (poultry, beef, veal and pork, sausages and lamb) (Agence Bio, 2017A).

In France like in all European countries, organic food must be labeled with the EUOrganic label (Rozporządzenie Rady, 834/2007). Consumer awareness about this label is steadily growing though it still has not exceeded $50 \%$ of the respondents. Additionally, in France there is a national labelling for organic agriculture $(\mathrm{AB})$, which is facultative (fig. 5). Knowledge of this labelling is common among French consumers (98\%) (Agence Bio/CSA, 2015).

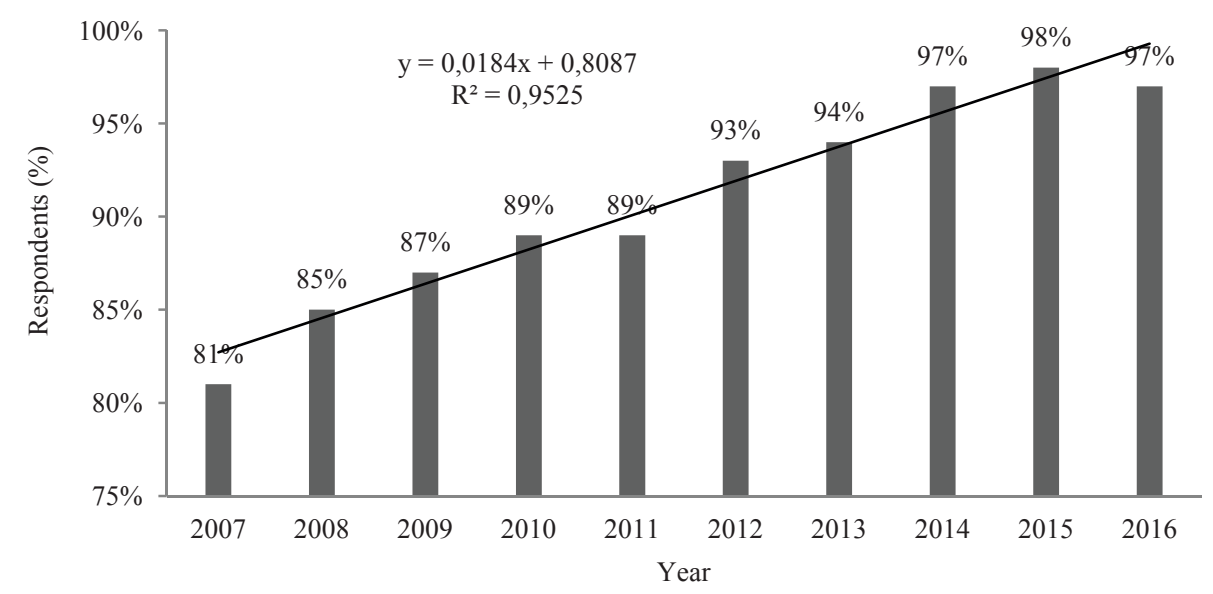

Fig. 5. Familiarity of French consumers with the national labelling AB (Agriculture biologique) 2007-2016 (\% respondents)

Source: Own research according to Baromètre de consommation et de perception des produitsbiologiquesen France 12ème édition - lère chase, Agence Bio/CSA. S.20, Le marche de la bio en France(2017). AgenceFrançaise pour le Développement et la Promotion de L'agricultureBiologique, 2017.

A linear trend in foundation of number and area of organic farms, number of organic entrepreneurs, size of organic food sale with distinct upward tendency was observed in this period. The value of determination coefficients indicated good consistence of the determined trend lines with empirical data $\left(R^{2}\right.$ from 0,932 to 0,969$)$.

\section{Importance of clusters}

Literature provides a number of benefits connected with participation in a cluster. Seven areas of benefits have been defined as well as their specificity resulting from the 
cluster functioning. These areas include: economic cooperation, innovations and technology, policy of authorities, cluster expansion, research and network creation, cooperation with institutions, education and training. Possibilities of using partners' experiences, access to high quality services, strengthening position in relation to suppliers and customers, possibility to obtain the benefit of specialization have been listed as components of the area of economic cooperation. The following subarea were assigned to the topic of innovation and technologies: diffusion of innovation within a cluster, combining financial means for investments, facilitating introduction of new technical solutions, determination of technical standards and introduction of innovation. Regarding the policy of authorities, the following factors determined: better cooperation with local authorities, supporting funds for public purposes, EU funds and cluster initiatives, infrastructure development, improvement in legislation. The next area of benefits is the expansion of clusters. This area involves creating a region brand, collective promotion of cluster products, presentation of cluster companies at fairs and exhibitions, promotion of the cluster companies, export, supporting expansion of the cluster companies on the domestic market, arrival of new cooperating companies, investigating new export markets. Benefits that are provided by the area "research and network creation" include: development of a network between companies and relations between people, submitting reports on the subject of clusters, improving awareness of companies on the subject of membership in clusters. As regards cooperation with other institutions, the following issues are focused on: significance of cooperation with experts and research centers, access to services offered by technological centers and to information about the market. The last area 'Education and trainings' includes access to specialist training courses in the field of technology, management, the adjustment of the educational system to the needs of the cluster participants and access to highly qualified staff (Plawgo, Klimczuk, 2009).

\section{Case - Study - Characteristics of the French „OrganicsCluster” (Overnia - RodanAlps)}

The cluster named "Organics Cluster" has existed in France since 2011. It is situated in the Rodan-Alpian region (currently Overnia - Rodan Alps). This region is characterized by a high level of innovation and well developed clusters as compared to the region of Europe. It is also the leader in the sector of organic products in France. This is reflected by the fact that the region is known as the French region with the largest number of organic farms as many as 2968 organic farms in its area. Organic processing is well developed as well, in the region in early 1053 organic processors exist. Distribution of organic products puts the analyzed region in second place of the rankings in whole France. According to statistics (Organic cluster, 2017), there are 317 specialist organic stores and 251 wholesale stores which offer organic products in their assortment. The purpose of a newly founded cluster is to strengthen the region and improve its competitiveness. According to the surveyed director, this goal is being pursued, "Organics Cluster" contributes to the development of the region and protection of the natural environment.

The cluster operation is organized as an association. 170 business entities make up the cluster and the number of its members is constantly increasing, as compared to 2012, when it was almost 3 times smaller (60 entities). Among cooperating organizations there are organic farms, food production companies as well as companies producing organic 
cosmetics and cleaning supplies. Such a differentiation of members, according to the director, is of unique character on a world scale. According to the director the major advantages of the 'Organics Cluster" include reception of regional support by the cluster members in order to use it for commercialization of products, innovation, and marketing on a national level and in the region, use of (exclusively) market research concerning organic products, access to the network by young entrepreneurs, making implementation of innovation subsequently easier and exchange of experiences. No disadvantages of the cluster were mentioned by the director.

The cluster has received public support for its functioning in the amount of 1 million euro from regional funds for SMEs (small and medium companies).

The major goals of a cluster include (Organic cluster, 2017):

- information - providing information to enable businesses to be competitive on the market,

- supporting businesses through organization of training courses (training in marketing, export, innovation),

- consolidation to improve efficiency (combining e.g. trade functions, common exhibitions, promotion e.g.)

Implementation of 112 projects as part of innovative (Bio'Innov) and export (Bio'Innov) actions was considered to be the most important outcome of the cluster. The projects were connected, among others, with promotion of organic projects (15 participating firms), providing firms with support to develop distribution channels and create environment friendly packaging ( 85 firms), organization of economic mission to Germany (8 firms) and creation of shared stalls e.g. in Dubai (6 firms). Additionally, 35 new solutions have been prepared to be later used by 180 companies (Organics Cluster en Rhône-Alpes, 2017). According to literature, well-functioning clusters are conductive to innovation and its diffusion, due to which the cluster members gain competitive advantage on the domestic market and even abroad (Figiel Kuberska., Kufer, 2014). The analyzed cluster is an example of such a situation.

A brand was created with graphics and word content referring to the geographic region and the bio-industry to promote the cluster (fig.6). Recently a regional brand has also been created as organic products (fig. 6) (Organic cluster, 2017).

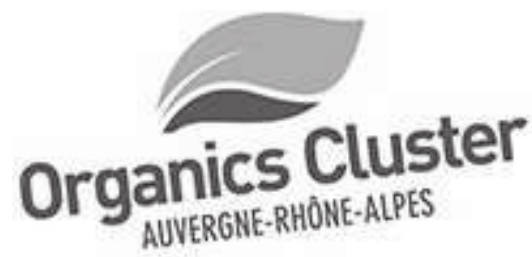

A

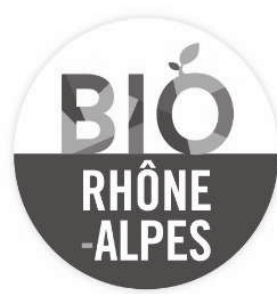

$\mathrm{B}$

Fig. 6. Brand Organics Cluster in France (A) and Regional organic brand (B)

Source: http://www.organics-cluster.com/, http://www.organics-cluster.com/hotline/charte-bio-rhone-alpesdeveloppement-secteur-produits-biologiques/. 
Organics cluster has also undertaken international cooperation as part of Inter - cluster organic, together with Aegean University, Aegean Organization of Exporters, Association of Organic Agriculture from Turkey, EkoConnect Organization from Germany, Organization for Organic Products from Greece, and in result of this the following projects have been implemented:

- Creation of an online platform to facilitate cooperation (for farmers, manufacturers, traders, associations, higher education schools and other organizations connected with the organic food market);

- Development of a system enabling comparison of processing of organic products with conventional ones;

- Preparation of an online platform for the sale of products;

- Selection and presentation of model examples of organic production and cooperation of businesses in the region.

So far five workshops have been organized in Turkey, Germany, France and Greece in order to provide the public with information on the effects of cooperation, a number of brochures have been published in English, French, German and Turkish as well as catalogues and posters (Inter-Cluster Organics, Developing European Inter-Cluster, 2012). Creation of a network of clusters is one of the latest market trends (Figiel, Kuberska, Kufel, 2014).

\section{Conclusion}

According to many authors this is the lack of intergration between the production and distribution chain links of organic products that is an obstacle in the development of the organic food market in Poland (Zuba, 2012).

Clusters are one form of possible integration for organic market users. Today integration is forced by market processes, globalization and constantly increasing market competition. The analyzed Organics-cluster in France is developing rapidly which proves its being successful. It needs to be mentioned that its organic farm-members have produced many positive outcomes, have taken advantage of the region support for commercialization, innovative and marketing actions on the territory of France and the region, the results of exclusive market research, easier (especially for young entrepreneurs) innovation implementation, and experience exchange. It was found that the total number of innovation and export related projects implemented in the selected cluster was 112. Thanks to them the cluster members can gain competitive advanatages on the domestic market and even abroad.

The presented Organic cluster can be a reference model of possible integration of the organic food market users worth following by the Polish organic food branch.

\section{Bibliography}

Agence Bio (2017A). La bio change d'échelle en preservantsesfondamentaux!

Agence Bio (2017B). Le marche de la bio en France (2017). Accessed 15 September 2017 from: http://www.agencebio.org/le-marche-de-la-bio-en-france. 
Agence Bio/CSA (2015). Baromètre de consommation et de perception des produitsbiologiques en France.12ème édition - 1ère chase, S.20.

Brodzicki, T., Szultka, S. (2002). Koncepcja klastrów a konkurencyjność przedsiębiorstw. Organizacja i kierowanie, 4(110), 45-60.

Developing European Inter-Cluster Alliance for organic agriculture. Biofach 2012. Accessed 10 April 2017 from: https://www.feedingknowledge.net.

Duczmala, W., Potwory, W. (eds.) (2010). Klastry i inicjatywy klastrowe w województwie opolskim. Wyższa Szkoła Zarządzania i Administracji w Opolu, Wydawnictwo Instytut Śląski, Opole.

European Observatory of Clusters. Accessed 24 April 2017 from: http://www.clusterobservatory.eu/

Figiel, S., Kuberska, D., Kufel, J. (2014). Modelowanie rozwoju klastrów rolno-żywnościowych w Polsce. IERiGŻ, Warszawa.

Innovation Clusters in Europe: A statistical analysis and overview of current policy support. DG ENTERPRISE AND INDUSTRY REPORT. EUROPEAN COMMISSION ENTERPRISE AND INDUSTRY DIRECTORATE-GENERAL. Accessed 15 April 2017 from: http://www.central2013.eu/fileadmin/ user_upload/Downloads/Tools_Resources/Cluster.pdf.

Inter-Cluster Organics. Über das Projekt. Accessed 15 April 2017 from: http://www.organikkumeler.org/g/ AboutProject.aspx.

Kacprzak, E. (2014). Funkcjonowanie klastrów rolno-żywnościowych na ekologicznym rynku rolnym w Polsce. Rozwój Regionalny i Polityka Regionalna, 26, 119-133.

Loda, M. (2012). Benchmarking-nowoczesna koncepcja zarządzania organizacją. Zakład Zarządzania, Instytut Politechniczny, Państwowa Wyższa Szkoła Zawodowa im. S. Pigonia, Krosno.

Organic cluster (2017). Accessed 15 June 2017 from: http://www.organics-cluster.com.

Organics Cluster en Rhône-Alpes - Axe innovation. Accessed 10 March 2017 from: http://www.ineedra.org/ france/DT1185557166/page/Le-Cluster-Organics.html.

Pilarska, C. (2013). Identyfikacja struktur klastrowych oraz efekty ich funkcjonowania w Unii Europejskiej. Studia Ekonomiczne, 156, 137-155.

Pilarska, C. (2010). Polityka oparta na klastrach w wybranych krajach Unii Europejskiej. Zeszyty Naukowe Polskie Towarzystwo Ekonomiczne Kraków, 8, 89-118.

Plawgo, B., Klimczuk, M. (2009). Przesłanki rozwoju klastrów w sektorach tradycyjnych. In: M. Juchniewicz (ed.) Czynniki i źródła przewagi konkurencyjnej. Wyd. UWM Olsztyn,

Porter, M.E. (2001). O konkurencji. Polskie Wydawnictwo Ekonomiczne Warszawa.

Prus, P. (2006). Opinie rolników na temat współpracy w ramach grup producentów rolnych. Roczniki Naukowe SERiA, 8(1), 150-153.

Prus, P. (2008). Rola grup producenckich w podnoszeniu konkurencyjności gospodarstw rolniczych. Roczniki Naukowe SERiA, 10(3), 456-461.

Rozporządznie Rady (WE) nr 834/2007 w sprawie produkcji ekologicznej i znakowania produktów ekologicznych i uchylające rozporządzenie (EWG) $\mathrm{nr}$ 2092/91 (Dz. Urz. UE L 189 z 20.07.2007 r. ze zm.).

Willer, H., Lernoud, J. (2017). The World of organic agriculture. Statistics and Emergeing. FiBL ans IFOAN Organics International.

Zuba, M. (2012). Szanse i bariery w integracji łańcucha żywności ekologicznej w Polsce. Zeszyty Naukowe WSEI seria Ekonomia, 3, 261-288. 